\title{
Effect of various model parameters on solar photovoltaic cell simulation: a SPICE analysis
}

\author{
Md. Nazmul Islam Sarkar ${ }^{*}$ (D)
}

\begin{abstract}
In this paper, all the models of PV cell, namely ideal single-diode model, single-diode $R_{\mathrm{s}}$ model, single-diode $R_{\mathrm{p}}$ model, the two-diode model, and the three-diode model, have been discussed. SPICE simulation is done to evaluate the impact of model parameters on the operation of PV cell. The effects of the parameters are discussed. The photocurrent, $/ L$, is proportional to irradiance, and the series resistance, $R_{S}$, reduces the short-circuit current and fill factor. The parallel resistance, $R_{p}$, reduces the open-circuit voltage, and both the diffusion diode and recombination diode reduce the open-circuit voltage value and fill factor. Finally, it is shown that an increase in cell operating temperature reduces the open-circuit voltage and fill factor and thus degrades the performance significantly.
\end{abstract}

Keywords: Photovoltaic modeling, SPICE simulation of PV cell, Single-diode model, Two-diode model, Solar cell modeling

\section{Background}

A photovoltaic (PV) cell generates electricity when it is illuminated by the sun or some other light sources. Small PV cells can be grouped to form panels, and panels can be grouped to form arrays. The tremendous growth of PV industry and the increased number of installed PV systems all over the world raised the need for supervision and simulation tools for PV systems. To understand the PV system in a better way, modeling the PV system in various operating and weather conditions is necessary (Soto et al. 2006; Carrero et al. 2007). The simulation is also useful for various purposes like: (1) to analyze and study the behavior of power converters when they are attached with the PV system (Camps et al. 2015; Eccher et al. 2015), (2) to simulate the behavior of maximum power point tracker (MPPT) (Bendib et al. 2015; Ishaque et al. 2014), and (3) to estimate the efficiency of the PV system (Khazaei et al. 2015; Sivakumar et al. 2015). In addition to these, the simulation can also be used to analyze various operational conditions like: partial shading,

*Correspondence: sarkarmni@gmail.com

Institute of Energy, University of Dhaka, Dhaka 1000, Bangladesh change in irradiance, and fault conditions (Brano et al. 2010, 2012).

On the other hand, manufacturers of the PV modules provide electrical parameters only at standard test conditions (STC) which are irradiance $=1000 \mathrm{~W} / \mathrm{m}^{2}, 1.5$ air mass (AM), and cell temperature of $T_{\text {cell }}=25{ }^{\circ} \mathrm{C}$ (Soto et al. 2006). Manufacturers datasheet only provides the short-circuit current $I_{\mathrm{SC}}$, open-circuit voltage $V_{\mathrm{OC}}$, the voltage at maximum power point $V_{\mathrm{MP}}$, the current at maximum power point $I_{\mathrm{MP}}$, and the temperature coefficients at open-circuit voltage and short-circuit current (Sera et al. 2007). However, the operating range of the PV panel is large and operating and weather conditions also vary. Therefore, performance models are built to predict the performance of the PV system at any operating and weather condition. The model predicts the I-V characteristic of a PV system as a function of irradiance, angle of incidence of solar radiation, the spectrum of sunlight, and temperature (Chatterjee et al. 2011). For the last few years, substantial amount of work has been done to develop simulation models and extraction of model parameters of photovoltaic systems (Chouder et al. 2012; Ma et al. 2014; Villalva et al. 2009; Castaner and Silvestre 
2002; Bal et al. 2012; Xie et al. 2014). Specially, Ma et al. (2014b) have developed a model to simulate the performance characteristics of crystalline silicon photovoltaic modules/strings/arrays. Zeroual et al. (1998) designed and constructed a closed loop sun-tracker with microprocessor management. Chin et al. (2011) have done a design, modeling, and testing of standalone single axis active solar tracker using MATLAB/Simulink. Chin (2012) has also done model-based simulation of an intelligent microprocessor-based standalone solar tracking system. Models for numerical device simulations of crystalline silicon solar cells were also reviewed by Altermatt (2011). De Blas et al. (2002) found suitable models for characterizing photovoltaic devices. Celik and Acikgoz (2007) have done the modeling and experimental verification of the operating current of monocrystalline photovoltaic modules using four- and five-parameter models. Chatterjee et al. (2011) have identified suitable photovoltaic source models. However, the effects of individual model parameters were not clearly reviewed in the present literature.

The objective of this work is to analyze the effects of model parameters on the simulation of PV cell. PSPICE is used to analyze and simulate the effects of parameters on photovoltaic cell performance.

\section{How a photovoltaic cell works?}

A photovoltaic cell is usually a semiconductor device that converts sunlight into electricity by the means of photovoltaic effect (Archer and Hill 2001). When light falls on a solar cell, the incoming photons can be absorbed, reflected, or passed through it. For a photon to be absorbed by the solar cell, the energy of the photon must be greater than the band gap energy of the cell (Luque and Hegedus 2011). The photon is then absorbed to generate pairs of mobile charge carriers (for example, electron and hole) which are then separated by the structure of the device (such as a $\mathrm{p}-\mathrm{n}$ junction). This produces a potential difference and thus produces electrical current. The photovoltaic effect is shown by various materials. In most of the cases, semiconductor materials (like silicon) in the form of $\mathrm{p}-\mathrm{n}$ junction are commercially used to produce solar cells (Green et al. 2015). The I-V characteristic of a $\mathrm{p}-\mathrm{n}$ junction diode is given by the Shockley equation as (Luque and Hegedus 2011):

$$
I_{D}=I_{0}\left[\exp \left(\frac{q V_{\mathrm{D}}}{n k T_{\text {cell }}}\right)-1\right]
$$

where $I_{\mathrm{D}}$ is the current generated by the diode, $V_{\mathrm{D}}$ is the voltage across the diode, $I_{0}$ is the reverse saturation current of the diode, $q=1.602 \times 10^{19}$ Coulombs is the electron charge, $T_{\text {cell }}$ is the cell temperature in Kelvin, $n$ is the diode ideality factor (dimensionless), and $k=1.38065 \times 10^{23} \mathrm{~J} / \mathrm{K}$ is the Boltzmann constant. The reciprocal term of $\left(q / n k T_{\text {cell }}\right)$ is called the thermal voltage of the diode. Therefore, thermal voltage of the diode is:

$$
V_{\mathrm{T}}=\frac{n k T_{\text {cell }}}{q}
$$

Now Eq. (1) becomes:

$$
I_{\mathrm{D}}=I_{0}\left[\exp \left(\frac{V_{\mathrm{D}}}{V_{\mathrm{T}}}\right)-1\right]
$$

The fill factor of a solar cell is given as:

$$
F F=\frac{V_{\mathrm{MPP}} I_{\mathrm{MPP}}}{V_{\mathrm{oc}} I_{\mathrm{sc}}}
$$

A semiconductor $\mathrm{p}-\mathrm{n}$ junction can be made to operate as a solar cell. Figure 1 shows the basic structure of a PV cell. When light is incident on the cell, the photons of light generate free electron-hole pairs which are then attracted toward the junction. Figure 2 illustrates the operation of the solar cell. In the cell, electron flows from n-type silicon to p-type silicon. The generated current is proportional to the light intensity Archer and Hill (2001).

\section{Different parameter models of solar cell}

There are various electrical circuit models of photovoltaic cells which have been widely described in the literature (Saloux et al. 2011; Ishaque et al. 2011a, b; Ishaque and Salam 2011; Ishaque et al. 2011). Usually, a PV cell is represented by a current source $\left(I_{\mathrm{ph}}\right)$, one or two diodes $(\mathrm{D})$ in parallel with the current source, a series resistance $\left(R_{\mathrm{S}}\right)$ or a parallel resistance $\left(R_{\mathrm{p}}\right)$ or both connected. The datasheet of a PV panel provided by the manufacturer usually includes few electrical and thermal parameters as given in Table 1. All these values are measured at standard test condition which is at 1.5 air mass (AM), $1000 \mathrm{~W} / \mathrm{m}^{2}$, and $25{ }^{\circ} \mathrm{C}$ temperature. Usually, the models are known by the unknown number of values of the parameters which cannot be deduced directly from datasheet values. In the preceding section, the models and their associated parameters are described.

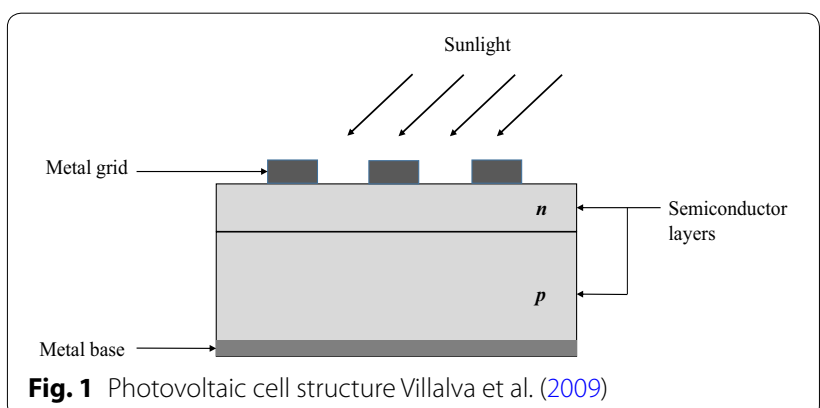




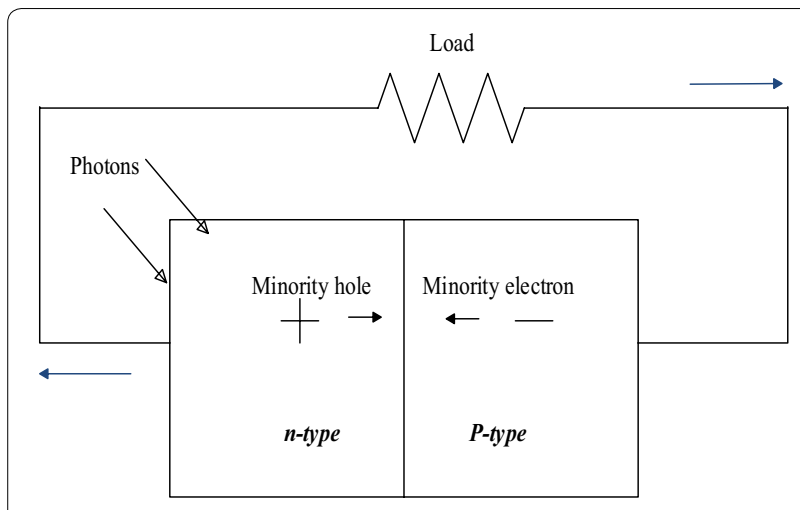

Fig. 2 Photovoltaic cell operation Luque and Hegedus (2011)

Table 1 Electrical and thermal parameters available from manufacturer datasheet

\begin{tabular}{ll}
\hline Parameters & Symbol (Unit) \\
\hline Electrical parameters & \\
Maximum power rating & $P_{\max }\left(W_{\mathrm{p}}\right)$ \\
Rated current & $I_{\mathrm{MPP}}(\mathrm{A})$ \\
Rated voltage & $V_{\mathrm{MPP}}(\mathrm{V})$ \\
Short-circuit current & $I_{S C}(\mathrm{~A})$ \\
Open-circuit voltage & $V_{O C}(\mathrm{~V})$ \\
Thermal parameters & \\
Normal operating cell temperature & $\mathrm{NOCT}\left({ }^{\circ} \mathrm{C}\right)$ \\
Temperature coefficient: short-circuit current & $\left(\mathrm{A} /{ }^{\circ} \mathrm{C}\right)$ \\
Temperature coefficient: open-circuit voltage & $\mathrm{V}\left({ }^{\circ} \mathrm{C}\right)$ \\
Standard test conditions $(S T C)$ & \\
Air mass & $\mathrm{AM}=1.5$ \\
Irradiance & $\mathrm{G}=1000 \mathrm{~W} / \mathrm{m}^{2}$ \\
Cell temperature & $T_{\text {cell }}={ }^{\circ} \mathrm{C}$ \\
\hline
\end{tabular}

\section{Ideal cell model}

In ideal condition, the solar cell is electrically equivalent to a current source in parallel with a diode as shown in Fig. 3a. The light-generated current, also known as photocurrent, is represented as $I_{\mathrm{L}}$, the diode current as $I_{\mathrm{D}}$, and the net current and terminal voltage of solar cell as $I_{\text {cell }}$ and $V_{\text {cell }}$, respectively. The net current $I_{\text {cell }}$ available from the PV cell is given as:

$$
I_{\text {cell }}=I_{\mathrm{L}}-I_{\mathrm{D}}
$$

Substituting the value of $I_{\mathrm{D}}$ from Eq. (3) into Eq. (4), we get:

$$
I_{\text {cell }}=I_{L}-I_{0}\left[\exp \left(\frac{V_{\text {cell }}}{\left.V_{\mathrm{T}}\right]}\right)-1\right]
$$

The photocurrent $I_{\mathrm{L}}$ increases linearly with solar insolation. If diode current $I_{\mathrm{D}}$ is small, more current is delivered by the PV cell. The diode ideality factor $n$ indicates how closely the diode follows the ideal diode equation (Archer and Hill 2001). The value of $n$ greater than 1 represents non-ideal condition, whereas $n=1$ represents ideal behavior of the diode.

As we can see from Eq. (3) that the ideal cell model has three parameters to find which are photocurrent $I_{\mathrm{L}}$, dark current $I_{0}$, and diode ideality factor A. Therefore, this ideal model is also called the 3-p (three-parameter) model as shown in Table 2. This ideal cell model can be used to demonstrate the basic concept of PV cell, but is never used to simulate the actual operating conditions. This is because there are several limitations present in a practical PV cell (Castaner and Silvestre 2002). The series resistive losses, the shunt resistive losses, the recombination at the space-charge region of solar cells which is non-ohmic, and the non-ideality of the diffusion diode all indicate that ideal single-diode model is insufficient to accurately represent the maximum power delivered by the PV cell (Luque and Hegedus 2011).

\section{Single-diode $R_{\mathrm{s}}$ model}

In fact, the current generated in the photovoltaic cell travels through semiconductor material which are not heavily doped and thus show resistivity (Duffie and Beckman 2006; Ma et al. 2014a). Besides this, the resistance of the metal grid, contacts, and current-collecting wires also contribute to the total series resistive losses. Usually, a lumped resistor, $R_{\mathrm{s}}$, is added in series with the ideal circuit model to represent these series losses as shown in Fig. 3b (Ma et al. 2014a). This model is called singlediode $R_{\mathrm{s}}$ model.

Because of the addition of the lumped series resistor, $R_{\mathrm{s}}$, the net current flow through the cell, $I_{\text {cell }}$, now becomes:

$$
\begin{aligned}
& I_{\text {cell }}=I_{\mathrm{L}}-I_{\mathrm{D}} \\
& I_{\text {cell }}=I_{\mathrm{L}}-I_{0}\left[\exp \left(\frac{V_{\text {cell }}+I_{\text {cell }} R_{\mathrm{s}}}{V_{\mathrm{T}}}\right)-1\right]
\end{aligned}
$$

From Eq. (4), it can be seen that there are now four unknown parameters: photocurrent $I_{\mathrm{L}}$, reverse saturation current $I_{0}$, diode ideality factor $\mathrm{A}$, and the newly added lumped series resistor $R_{\mathrm{s}}$. This model is therefore named as 4-p model. However, in recent research it is shown that the 4-p model which ignores the shunt resistance effect does not perfectly fit the experimental $\mathrm{I}-\mathrm{V}$ and $\mathrm{P}-\mathrm{V}$ data (Dongue et al. 2012).

\section{Single-diode $R_{\mathrm{p}}$ model}

As the solar cells are made out of large area wafers, or from large area thin film material, a number of shunt resistive losses occur at $n$ layer of the $\mathrm{p}-\mathrm{n}$ junction PV cell. Localized short circuit or short circuiting of the cell 


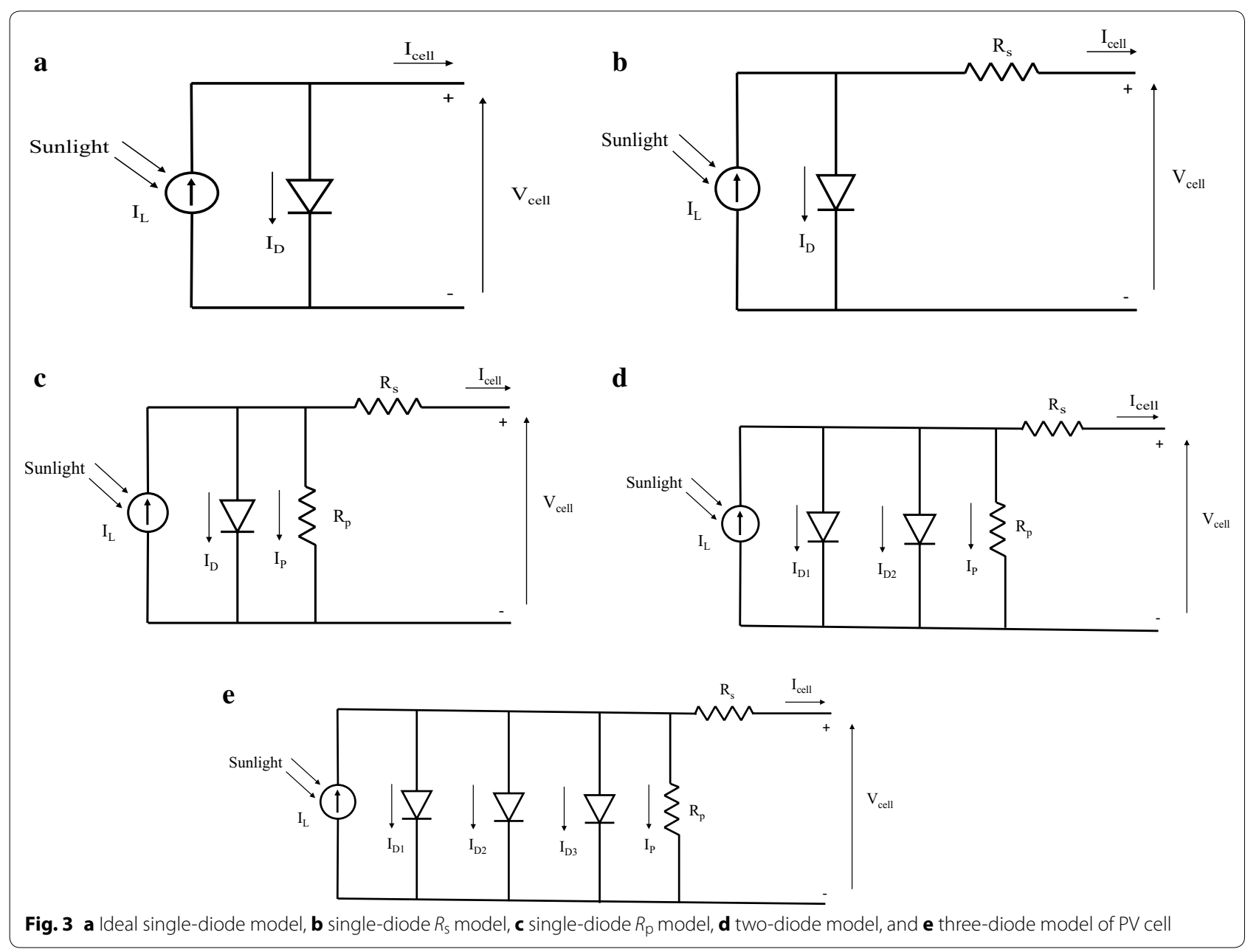

Table 2 Model parameters of different models

\begin{tabular}{|c|c|c|c|}
\hline Models & No. of parameters & Parameters & Parameter meanings \\
\hline Ideal single-diode model & 3 & $L_{L} / l_{0}, n_{1}$ & $\iota$, the photocurrent \\
\hline Single-diode $R_{s}$ model & 4 & $L_{L}, I_{01}, n_{1}, R_{S}$ & $I_{01}$ the reverse saturation current of the first diode \\
\hline Single-diode Rp model & 5 & $L, I_{01}, n_{1}, R_{\mathrm{s}}, R_{\mathrm{p}}$ & $1_{02}$, the reverse saturation current of the second diode \\
\hline Two-diode model & 7 & $L_{L}, I_{01}, I_{02}, n_{1}, n_{2}, R_{\mathrm{S}}, R_{\mathrm{p}}$ & $I_{03}$, the reverse saturation current of the third diode \\
\hline \multirow[t]{5}{*}{ Three-diode model } & 9 & $L_{L}, I_{01}, I_{02}, I_{03}, n_{1}, n_{2}, n_{3}, R_{\mathrm{s}}, R_{\mathrm{p}}$ & $n_{1}$, the first diode ideality factor \\
\hline & & & $n_{2}$, the second diode ideality factor \\
\hline & & & $n_{3,}$ the third diode ideality factor \\
\hline & & & $R_{\mathrm{S},}$ lumped series resistance \\
\hline & & & $R_{\mathrm{p}}$, shunt resistance \\
\hline
\end{tabular}

border are the most common form of shunt losses (Castaner and Silvestre 2002). This is represented generally by a lumped resistor, $R_{\mathrm{sh}}$, in parallel with the ideal device. The single-diode $R_{\mathrm{p}}$ model which has both the series resistance $R_{\mathrm{s}}$ and shunt resistance $R_{\mathrm{p}}$ is shown in Fig. 3c. As there are five unknown parameters in this model, it is called the 5-p model. Table 2 illustrates the models along with their parameters. The current through the parallel resistor, $I_{\mathrm{P}}$, can be given as:

$$
I_{\mathrm{P}}=\frac{\left(V_{\text {cell }}+I R_{\mathrm{s}}\right)}{R_{\mathrm{p}}}
$$


The governing equation of this 5 -p model now becomes:

$$
I_{\text {cell }}=I_{\mathrm{L}}-I_{D}-I_{\mathrm{P}}
$$

$I_{\text {cell }}=I_{\mathrm{L}}-I_{0}\left[\exp \left(\frac{V_{\text {cell }}+I_{\text {cell }} R_{\mathrm{s}}}{V_{\mathrm{T}}}\right)-1\right]-\frac{\left(V_{\text {cell }}+I R_{\mathrm{s}}\right)}{R_{\mathrm{p}}}$

This single-diode $R_{\mathrm{p}}$ model or 5-p model is the most widely used and accepted model found in the literature (Chatterjee et al. 2011; Chenni et al. 2007; Chin et al. 2015; Ciulla et al. 2014; Mahmoud et al. 2012; Patel and Agarwal 2008; Brano et al. 2010, 2012). Most of the research has been done on the improved 5-p model and its parameter $\left(I_{\mathrm{L}}, I_{0}, V_{T}, R_{\mathrm{s}}, R_{\mathrm{p}}\right)$ extraction procedure (Soto et al. 2006; Brano et al. 2010, 2012; Sera et al. 2007; Chatterjee et al. 2011; Villalva et al. 2009; Ishaque et al. 2011).

\section{Two-diode model}

Even though the commonly used 5-p model can achieve acceptable level of accuracy, the saturation current of the photovoltaic cell is the linear superposition of charge diffusion and recombination in the space-charge layer (Luque and Hegedus 2011) and therefore the more accurate electrical representation of the PV cell can be done by two Shockley diodes in parallel with a current source and associated series and shunt resistances (Castaner and Silvestre 2002). This model is more relevant at low-voltage bias, i.e., at low irradiance level operation of the PV cell (Luque and Hegedus 2011). Figure 3d illustrates the circuit of this model.

The equivalent circuit equation of the two-diode model is given as:

$$
\begin{aligned}
I_{\text {cell }}=I_{\mathrm{L}}-I_{D 1}-I_{D 2}-I_{P} \\
I_{\text {cell }}=I_{\mathrm{L}}-I_{01}\left[\exp \left(\frac{V_{\text {cell }}+I_{\text {cell }} R_{\mathrm{s}}}{V_{T 1}}\right)-1\right] \\
-I_{02}\left[\exp \left(\frac{V_{\text {cell }}+I_{\text {cell }} R_{\mathrm{s}}}{V_{T 2}}\right)-1\right]-\frac{\left(V_{\text {cell }}+I R_{\mathrm{s}}\right)}{R_{\mathrm{p}}}
\end{aligned}
$$

We can see form Table 2 that the number of parameters is increased to seven in two-diode model. To reduce the number of unknowns, the ideality factor of the first diode is usually taken as 1 and the second diode ideality factor is taken as 2 . This assumption is done based on the approximation of Shockley-ReadHall recombination in the space-charge layer of the photodiode (Chih-Tang et al. 1957). Unfortunately, this assumption does not always hold true (McIntosh et al. 2000).

\section{Three-diode model}

To take the influence of grain boundaries and leakage current through the peripheries into consideration, another diode can be added in parallel with the two other diodes of the two-diode model (Nishioka et al. 2007). This model has nine parameters (see Table 2) and a really cumbersome solution process. Most of the time, ignoring few parameters is done to reduce the number of equations of this model. Figure 3e shows the circuit diagram of this model.

The equation of the current of this model is:

$$
\begin{aligned}
I_{\text {cell }} & =I_{\mathrm{L}}-I_{D 1}-I_{D 2}-I_{D 3}-I_{\mathrm{P}} \\
I_{\text {cell }}= & I_{\mathrm{L}}-I_{01}\left[\exp \left(\frac{V_{\text {cell }}+I_{\text {cell }} R_{\mathrm{s}}}{V_{T 1}}\right)-1\right] \\
& -I_{02}\left[\exp \left(\frac{V_{\text {cell }}+I_{\text {cell }} R_{\mathrm{s}}}{V_{T 2}}\right)-1\right] \\
& -I_{03}\left[\exp \left(\frac{V_{\text {cell }}+I_{\text {cell }} R_{\mathrm{s}}}{V_{T 3}}\right)-1\right]-\frac{\left(V_{\text {cell }}+I R_{\mathrm{s}}\right)}{R_{\mathrm{p}}}
\end{aligned}
$$

This model is usually used to extract the electrical properties of multicrystalline Si solar cells. Because of the complexity of the parameter extraction process of threediode model, the use of this model is quite limited (Ma et al. 2014a).

\section{Experimental setup}

Siemens SM50 module is connected in series with variable resistors, and current and voltages are measured for varying parameters. An Eppley PSP pyranometer is used to take the radiation measurement. The pyranometer gives output in a range of $0-10 \mathrm{mV}$ having sensitivity of approximately $8 \mu \mathrm{V} / \mathrm{Wm}^{-2}$. The SM50 module has 36 monocrystalline silicon solar cells. The electrical and thermal parameters of this module are enlisted in Table 3. Two digital multimeters are used to take current and voltage measurements. Figure 4 shows the experimental setup.

\section{Results and discussion}

Simulation Program with Integrated Circuit Emphasis or SPICE is an open-source circuit simulator developed by Nagel and Pederson of University of California, Berkeley, in 1973 (Nagel and Pederson 1973). With time, SPICE became popular and adopted by various institutions. Several proprietary software tool gradually evolved from the basic SPICE. Cadence OrCAD PSPICE is a similar proprietary software tool used to simulate circuit using SPICE. In this study, we have simulated the parameters shown in Table 2 to check their effects on the PV system 
Table 3 Electrical and thermal parameters of SM50 module

\begin{tabular}{lll}
\hline Electrical parameters & & \\
\hline Maximum power rating, $P_{\max }$ & (Wp) & 50 \\
Rated current $I_{\text {MPP }}$ & (A) & 3.05 \\
Rated voltage $V_{\text {MPP }}$ & $(\mathrm{V})$ & 16.6 \\
Short-circuit current $I_{S C}$ & $(\mathrm{~A})$ & 3.4 \\
Open-circuit voltage $V_{\mathrm{OC}}$ & $(\mathrm{V})$ & 21.4 \\
Thermal parameters & & \\
NOCT & $\left({ }^{\circ} \mathrm{C}\right)$ & $45 \pm 2$ \\
Temp. coefficient: short-circuit current & & $1.2 \mathrm{~mA} /{ }^{\circ} \mathrm{C}$ \\
Temp. coefficient: open-circuit voltage & & $-0.077 \mathrm{~V} /{ }^{\circ} \mathrm{C}$ \\
\hline
\end{tabular}

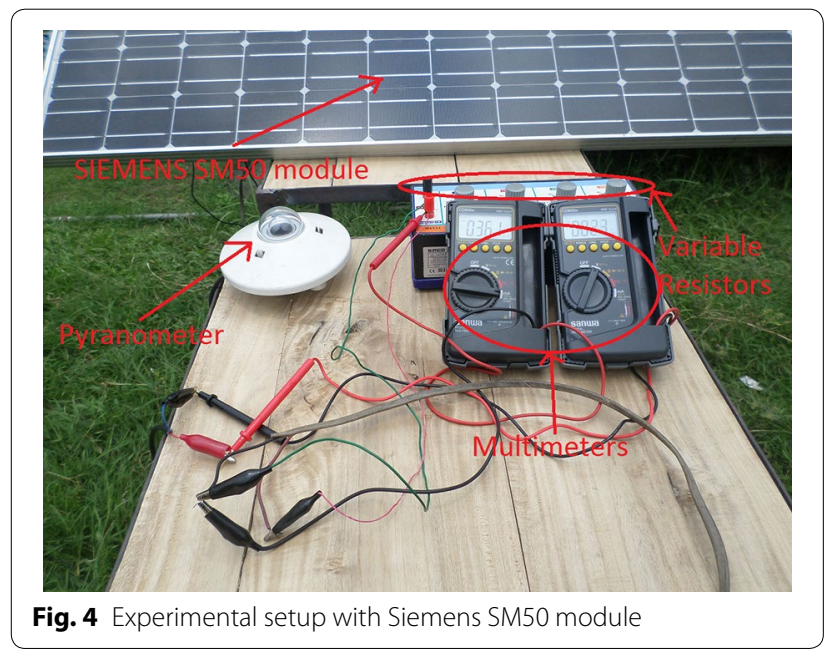

performance. For this purpose, we have taken a hypothetical small PV cell with an area of $5 \mathrm{sq}$. inch, short-circuit current density $34.3 \mathrm{~mA} / \mathrm{cm}^{2}$, and dark current $I_{0}$ as $10^{-11} \mathrm{~A} / \mathrm{cm}^{2}$. Using a PSPICE function named PROBE, we got the simulation curves. The schematic diagram of the simulation is given in Fig. 5.
Effect of photocurrent, $I_{\mathrm{L}}$

The photocurrent $I_{\mathrm{L}}$ is directly proportional to the irradiance received by the PV cell. The value of $I_{\mathrm{L}}$ can be calculated as:

$$
I_{\mathrm{L}}=\frac{J_{s c} A \times G}{1000}
$$

where $J_{s c}$ is the short-circuit current density $\left(\mathrm{mA} / \mathrm{cm}^{2}\right)$, $A$ is the area of the PV cell $\left(\mathrm{cm}^{2}\right)$, and G is the irradiance $\left(\mathrm{W} / \mathrm{m}^{2}\right)$. By changing the value of $\mathrm{G}$, we got several curves as shown in Fig. 6a. It is evident from the curves that the short-circuit current reduces significantly with reducing G. The fill factor (Eq. 4) also reduces to a great extent. Figure $6 \mathrm{~b}$ shows the simulated power curves of the PV cell with varying irradiance. Power also reduces proportionally with irradiance.

\section{Effects of the series resistance, $R_{\mathrm{s}}$}

From Fig. 7, it can be seen that with the increase in series resistance $R_{\mathrm{S}}$ the open-circuit voltage remains the same, but both the short-circuit current and fill factor reduce significantly. In practice, the value of the lumped series resistance $R_{\mathrm{s}}$ is kept quite low to prevent this drastic degradation in performance.

\section{Effects of the shunt resistance, $R_{\mathrm{p}}$}

By doing a dc sweep using PSPICE, the effect of the shunt resistance can be found. Figure 8 shows the I-V curves with varying shunt resistance $R_{\mathrm{s}}$. From the figure, it can be seen that the value of open-circuit current remains same, but short-circuit current and fill factor reduce with the increase in shunt resistance.

Effects of the diffusion and recombination diode, $D_{1}$ and $D_{2}$ Usually the diffusion diode, $D_{1}$, has an ideality factor close to unity. But in practice, because of the fabrication process, some non-ideality may remain. Similarly, the recombination diode should have the ideality factor as 2 . But it also exhibits some extents of non-ideality because

\section{PARAMETERS:}

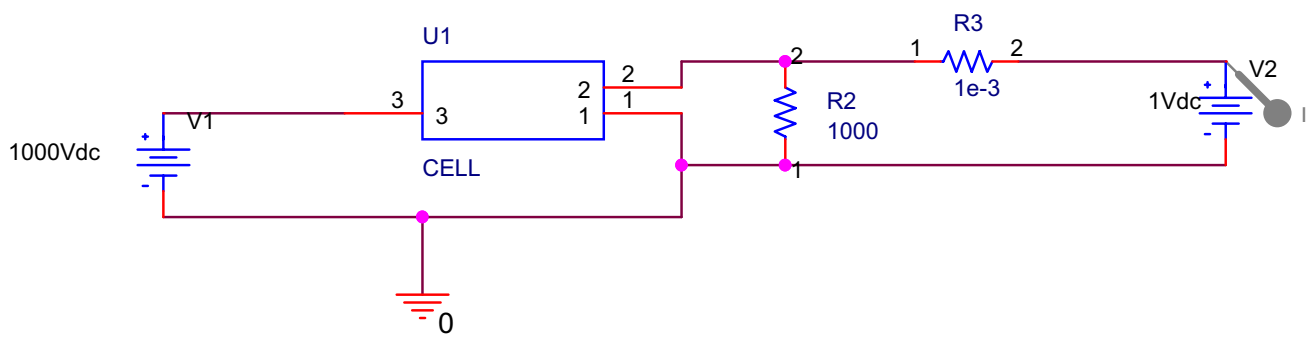

Fig. 5 Schematic diagram of PV cell simulation in PSPICE 

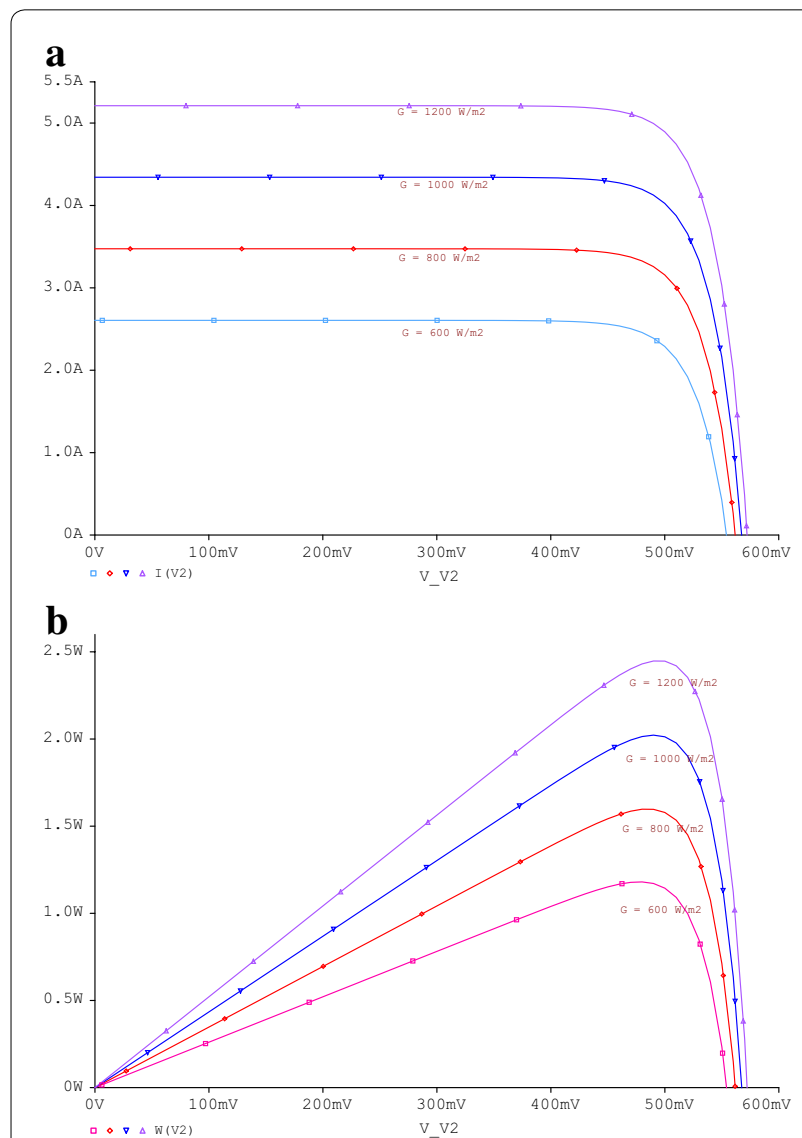

Fig. 6 a $\mid-V$ curves, and $\mathbf{b}$ power curves with varying irradiance

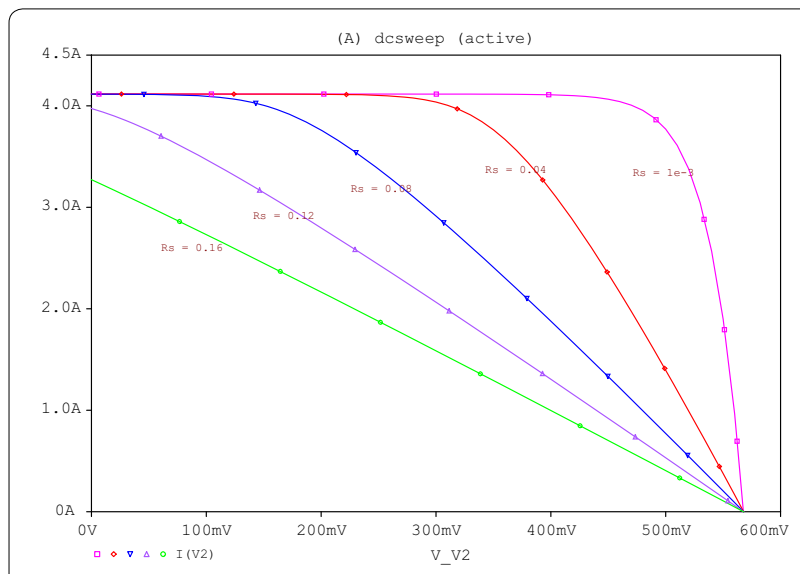

Fig. 7 Effect of series resistance, $R_{5}$

of the manufacturing process. The impact of both $D_{1}$ and $D_{2}$ is shown in Fig. 9a, b. It is evident that in both cases the short-circuit current remains same, but the open-circuit voltage and fill factor reduce to great extent.

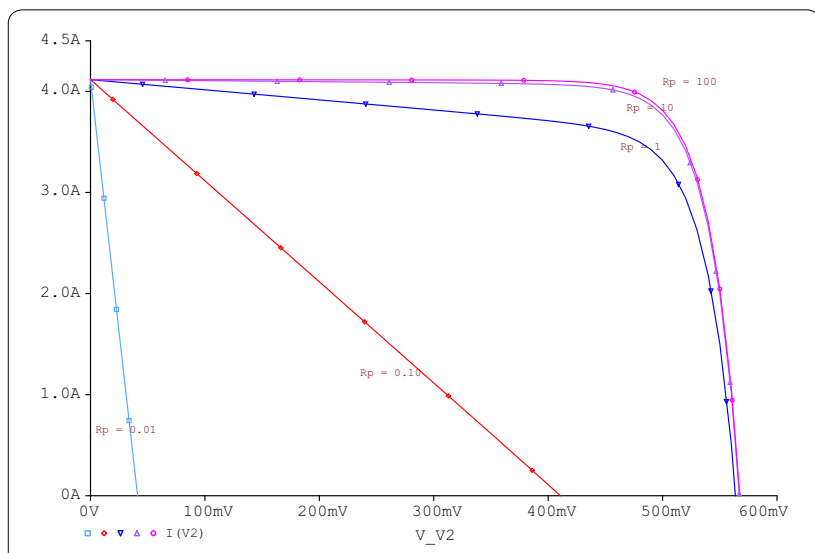

Fig. 8 I-V curves with varying shunt resistance, $R_{p}$

\section{Temperature effects, $T_{\text {cell }}$}

Because of the semiconductive property of the solar cell, temperature has a strong effect on its performance. In practice, solar cell can easily be warmed up to $60-65^{\circ} \mathrm{C}$. Using the built-in feature temperature sweep of PSPICE, we can check the effect of temperature on solar cell operation. Figure 10 shows the effect of cell temperature on its performance. It is seen that increased cell temperature reduces the open-circuit voltage and fill factor and thus reduces its performance significantly.

\section{Experimental results}

The experimental I-V curves provided by the manufacturer at different illumination and ambient temperature are shown in Fig. 11a. The measured I-V curve at $45^{\circ} \mathrm{C}$ and approximately $800 \mathrm{~W} / \mathrm{m}^{2}$ is shown at Fig. $11 \mathrm{~b}$. From the figures, it is clear that with the increase in insolation short-circuit current increases drastically, but opencircuit voltage does not increase that much. With the increase in temperature, short-circuit current does not decrease, but open-circuit voltage decreases a lot. The experimental results match with the simulation perfectly.

\section{Conclusion}

The development of PV system raised the need of simulation of PV system. In this paper, all the modeling methods have been discussed and SPICE simulation is done to evaluate the impact of model parameters on the operation of PV cell. The models discussed here are ideal single-diode model, single-diode $R_{\mathrm{s}}$ model, single-diode $R_{\mathrm{p}}$ model, the two-diode model, and the three-diode model. All the model parameters are enlisted in Table 2. The effect of the parameters are discussed with PSPICE simulation. The photocurrent, $I_{\mathrm{L}}$, is proportional to irradiance, and the series resistance, $R_{\mathrm{s}}$, reduces the short-circuit 


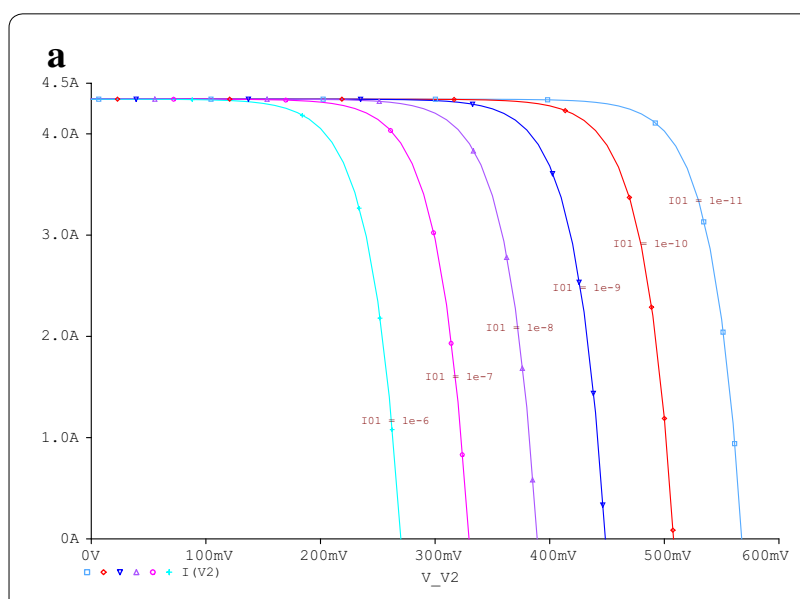

b

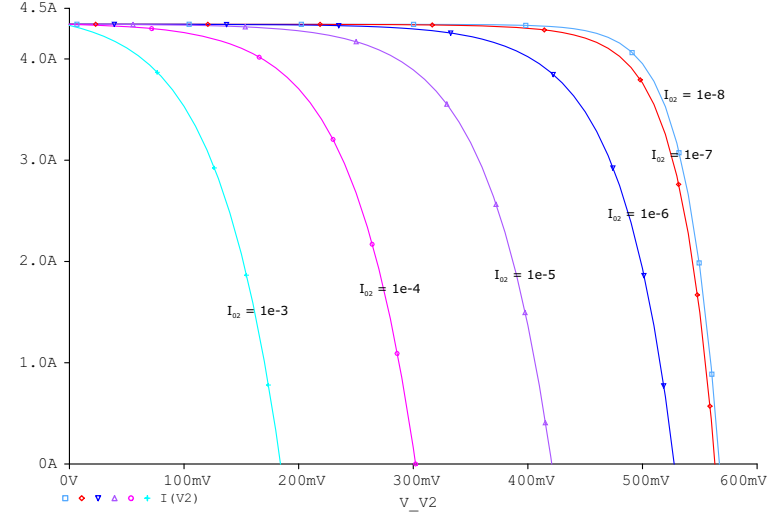

Fig. 9 Effects of diffusion diode: a I-V curves with varying dark current, $I_{01}$, and effects of recombination diode: $\mathbf{b}$ I-V curves with varying dark current, $I_{02}$

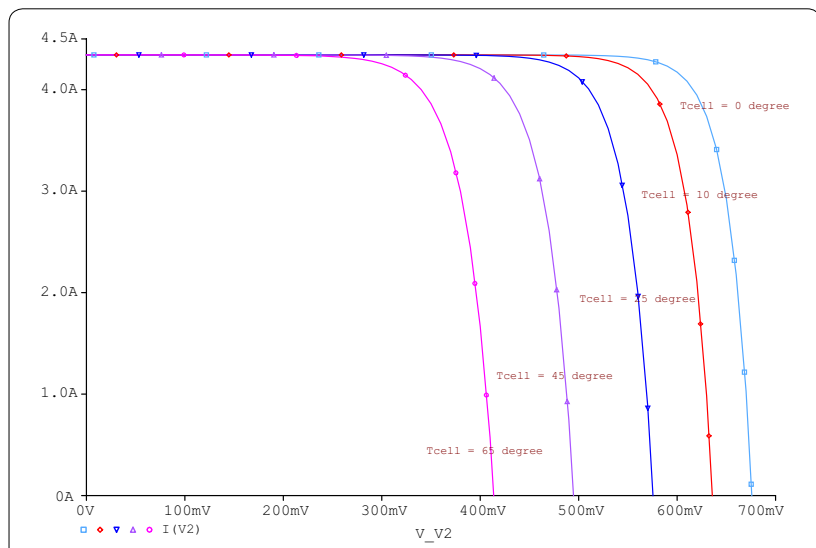

Fig. 10 Effect of operating temperature variation on the performance of PV cell

current and fill factor. The parallel resistance, $R_{\mathrm{p}}$, reduces the open-circuit voltage, and both the diffusion diode and recombination diode reduce the open-circuit voltage

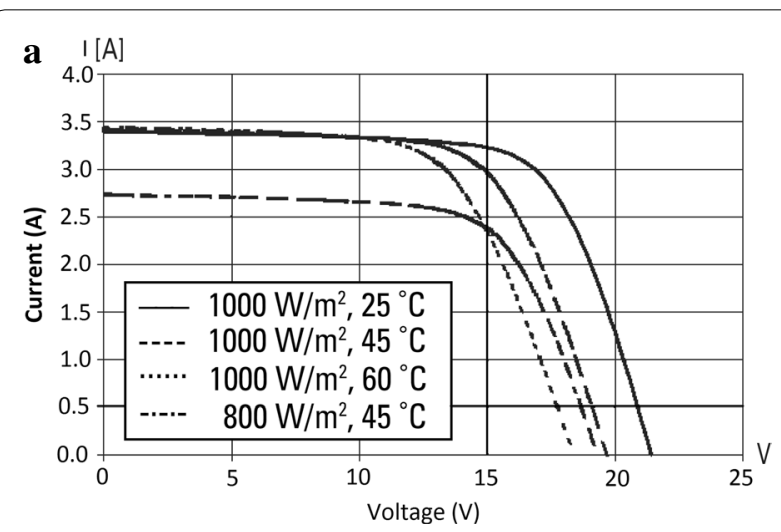

b

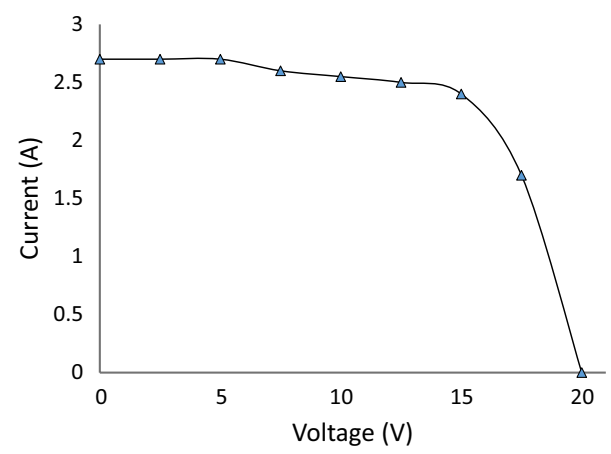

Fig. 11 Experimental I-V curves a provided by the manufacturer at different illumination and ambient temperature and $\mathbf{b}$ measured at $45^{\circ} \mathrm{C}$ and approximately $800 \mathrm{~W} / \mathrm{m}^{2}$

value. Finally, the increase in cell operating temperature reduces the open-circuit voltage and fill factor and thus degrades the performance significantly.

Competing interests

The author declare that he has no competing interests.

Received: 9 April 2016 Accepted: 12 July 2016

Published online: 12 August 2016

\section{References}

Altermatt, P. P. (2011). Models for numerical device simulations of crystalline silicon solar cells-a review. Journal of Computational Electronics, 10(3), 314-330. doi:10.1007/s10825-011-0367-6.

Archer, M. D., \& Hill, R. (2001). Clean electricity from photovoltaics. London: Imperial College Press.

Bal, S., Anurag, A. \& Babu, B.C. (2012). Comparative analysis of mathematical modeling of photovoltaic (pv) array. In India conference (INDICON), 2012 Annual IEEE (pp. 269-274).

Bendib, B., Belmili, H., \& Krim, F. (2015). A survey of the most used MPPT methods: Conventional and advanced algorithms applied for photovoltaic systems. Renewable and Sustainable Energy Reviews, 45, 637-648. doi:10.1016/j.rser.2015.02.009.

Brano, V. L., Orioli, A., \& Ciulla, G. (2012). On the experimental validation of an improved five-parameter model for silicon photovoltaic modules. Solar Energy Materials \& SolarCells, 105, 27-39.

Brano, V. L., Orioli, A., Ciulla, G., \& Gangi, A. D. (2010). An improved five-parameter model for photovoltaic modules. Solar Energy Materials \& SolarCells, 94, 1358-1370. 
Camps, X., Velasco, G., de la Hoz, J., \& Martin, H. (2015). Contribution to the PVto-inverter sizing ratio determination using a custom flexible experimental setup. Applied Energy, 149, 35-45. doi:10.1016/j.apenergy.2015.03.050.

Carrero, C., Amador, J., \& Arnaltes, S. (2007). A single procedure for helping pv designers to select silicon pv modules and evaluate the loss resistances. Renewable Energy, 32, 2579-2589.

Castaner, L., \& Silvestre, S. (2002). Modelling Photovoltaic Systems using PSpice. London: Wiley.

Celik, A. N., \& Acikgoz, N. (2007). Modelling and experimental verification of the operating current of mono-crystalline photovoltaic modules using fourand five-parameter models. Applied Energy, 84(1), 1-15. doi:10.1016/j. apenergy.2006.04.007.

Chatterjee, A., Keyhani, A., \& Kapoor, D. (2011). Identification of photovoltaic source models. IEEE Transactions on Energy Conversion, 26(3), 883-889.

Chenni, R., Makhlouf, M., Kerbache, T., \& Bouzid, A. (2007). A detailed modeling method for photovoltaic cells. Energy, 32(9), 1724-1730. doi:10.1016/j. energy.2006.12.006.

Chih-Tang, S., Noyce, R. N., \& Shockley, W. (1957). Carrier generation and recombination in $\mathrm{p}-\mathrm{n}$ junctions and $\mathrm{p}-\mathrm{n}$ junction characteristics. Proceedings of the IRE, 45(9), 1228-1243. doi:10.1109/JRPROC.1957.278528.

Chin, C., Babu, A., \& McBride, W. (2011). Design, modeling and testing of a standalone single axis active solar tracker using matlab/simulink. Renewable Energy, 36(11), 3075-3090.

Chin, V. J., Salam, Z., \& Ishaque, K. (2015). Cell modelling and model parameters estimation techniques for photovoltaic simulator application: A review. Applied Energy, 154, 500-519.

Chin, C. (2012). Model-based simulation of an intelligent microprocessorbased standalone solar tracking system. INTECH Open Access Publisher

Chouder, A., Silvestre, S., Sadaoui, N., \& Rahmani, L. (2012). Modeling and simulation of a grid connected pv system based on the evaluation of main pv module parameters. Simulation Modelling Practice and Theory, 20, 46-58.

Ciulla, G., Brano, V. L., Dio, V. D., \& Cipriani, G. (2014). A comparison of different one-diode models for the representation of iv characteristic of a PV cell. Renewable and Sustainable Energy Reviews, 32, 684-696. doi:10.1016/j. rser.2014.01.027.

de Blas, M., Torres, J., Prieto, E., \& Garcia, A. (2002). Selecting a suitable model for characterizing photovoltaic devices. Renewable Energy, 25(3), 371-380. doi:10.1016/S0960-1481(01)00056-8.

Dongue, S. B., Njomo, D., Tamba, J. G., \& Ebengai, L. (2012). Modeling of electrical response of illuminated crystalline photovoltaic modules using fourand five-parameter models. International Journal of Emerging Technology and Advanced Engineering, 2(11), 612-619.

Duffie, J. A., \& Beckman, W. A. (2006). Solar engineering of thermal processes (3rd ed.). Hoboken, New Jersey: Wiley.

Eccher, M., Salemi, A., Turrini, S., \& Brusa, R. (2015). Measurements of power transfer efficiency in CPV cell-array models using individual DC-DC converters. Applied Energy, 142, 396-406. doi:10.1016/j.apenergy.2014.12.038.

Green, M. A., Emery, K., Hishikawa, Y., Warta, W., \& Dunlop, E. D. (2015). Solar cell efficiency tables (version 45). Progress in Photovoltaics: Research and Applications, 23, 1-9. doi:10.1002/pip.2573.

Ishaque, K., \& Salam, Z. (2011). An improved modeling method to determine the model parameters of photovoltaic (pv) modules using differential evolution (de). Solar Energy, 85(9), 2349-2359. doi:10.1016/j. solener.2011.06.025

Ishaque, K., Salam, Z., \& Lauss, G. (2014). The performance of perturb and observe and incremental conductance maximum power point tracking method under dynamic weather conditions. Applied Energy, 119, 228-236. doi:10.1016/j.apenergy.2013.12.054.

Ishaque, K., Salam, Z., \&Taheri, H. (2011a). Simple, fast and accurate two-diode model for photovoltaic modules. Solar Energy Materials and Solar Cells, 95(2), 586-594. doi:10.1016/j.solmat.2010.09.023.

Ishaque, K., Salam, Z., Taheri, H., \& Shamsudin, A. (2011b). A critical evaluation of EA computational methods for photovoltaic cell parameter extraction based on two diode model. Solar Energy, 85(9), 1768-1779. doi:10.1016/j. solener.2011.04.015
Khazaei, J., Miao, Z., Piyasinghe, L., \& Fan, L. (2015). Real-time digital simulationbased modeling of a single-phase single-stage PV system. Electric Power Systems Research, 123, 85-91. doi:10.1016/j.epsr.2015.01.023.

Luque, A., \& Hegedus, S. (2011). Handbook of photovoltaic science and engineering (2nd ed.). London: Wiley.

Ma, T., Yang, H., \& Lu, L. (2014a). Solar photovoltaic system modeling and performance prediction. Renewable and Sustainable Energy Reviews, 36, 304-315.

Ma, T., Yang, H., \& Lu, L. (2014b). Development of a model to simulate the performance characteristics of crystalline silicon photovoltaic modules/ strings/arrays. Solar Energy, 100, 31-41. doi:10.1016/j.solener.2013.12.003.

Mahmoud, Y., Xiao, W., \& Zeineldin, H. H. (2012). A simple approach to modeling and simulation of photovoltaic modules. IEEE Transactions on Sustainable Energy, 3(1), 185-186. doi:10.1109/TSTE.2011.2170776.

Mclntosh, K. R., Altermatt, P. P. \& Heiser, G. (2000). Depletion-region recombination in silicon solar cells: when does $m_{D R}=2$ ? In Proceedings of the 16th european photovoltaic solar energy conference

Nagel, L. W. \& Pederson, D. (1973). Spice (simulation program with integrated circuit emphasis). Tech. Rep. UCB/ERL M382, EECS Department, University of California, Berkeley. http://www.eecs.berkeley.edu/Pubs/ TechRpts/1973/22871.html

Nishioka, K., Sakitani, N., Uraoka, Y., \& Fuyuki, T. (2007). Analysis of multicrystalline silicon solar cells by modified 3-diode equivalent circuit model taking leakage current through periphery into consideration. Solar Energy Materials and Solar Cells, 91(13), 1222-1227. doi:10.1016/j.solmat.2007.04.009.

Patel, H., \& Agarwal, V. (2008). Matlab-based modeling to study the effects of partial shading on pv array characteristics. IEEE Transactions on Energy Conversion, 23(1), 302-310. doi:10.1109/TEC.2007.914308.

Saloux, E., Teyssedou, A., \& Sorin, M. (2011). Explicit model of photovoltaic panels to determine voltages and currents at the maximum power point. Solar Energy, 85(5), 713-722. doi:10.1016/j.solener.2010.12.022.

Sera, D., Teodorescu, R. \& Rodriguez, P. (2007). PV panel model based on datasheet values. In IEEE international symposium on industrial electronics, 2007, ISIE 2007 (pp. 2392-2396). doi:10.1109/ISIE.2007.4374981

Sivakumar, P., Kader, A. A., Kaliavaradhan, Y., \& Arutchelvi, M. (2015). Analysis and enhancement of PV efficiency with incremental conductance mppt technique under non-linear loading conditions. Renewable Energy, 81, 543-550. doi:10.1016/j.renene.2015.03.062.

Soto, W. D., Klein, S. A., \& Beckman, W. A. (2006). Improvement and validation of a model for photovoltaic array performance. Solar Energy, 80, 78-88.

Villalva, M. G., Gazoli, J. R., \& Filho, E. R. (2009). Comprehensive approach to modeling and simulation of photovoltaic arrays. IEEE Transactions on Power Electronics, 24(5), 1198-1208.

Xie, Y., Huang, J., Liu, X., Zhuo, F., Liu, B. \& Zhang, H. (2014) Pv system modeling and a global-planning design for its controller parameters. In 2014 twenty-ninth annual IEEE applied power electronics conference and exposition (APEC) (pp. $3132-3135)$.

Zeroual, A., Raoufi, M., Ankrim, M., \& Wilkinson, A. (1998). Design and construction of a closed loop sun-tracker with microprocessor management. International Journal of Solar Energy, 19(4), 263-274.

\section{Submit your manuscript to a SpringerOpen ${ }^{\circ}$ journal and benefit from:}

- Convenient online submission

- Rigorous peer review

- Immediate publication on acceptance

- Open access: articles freely available online

- High visibility within the field

- Retaining the copyright to your article

Submit your next manuscript at springeropen.com 